\title{
THE BODY/VENOUS HEMATOCRIT RATIO: ITS CONSTANCY OVER A WIDE HEMATOCRIT RANGE
}

\author{
By H. CHAPLIN, JR.,1 P. L. MOLLISON AND H. VETTER 2 \\ (From the Medical Research Council's Blood Transfusion Research Unit and Radiotherapeutic \\ Research Unit, Postgraduate Medical School of London, London, England)
}

(Submitted for publication June 18, 1953; accepted July 23, 1953)

Most observers have found that when circulating red cell volume is deduced from measurement of plasma volume and venous hematocrit a higher value is obtained than when the red cell volume is measured directly. It is widely believed that this is because the proportion of red cells in the blood in large vessels is higher than that in the body as a whole and various correction factors have been proposed. Some confusion arises because the venous hematocrit must be corrected on two accounts : firstly because, under standard conditions of centrifugation, some plasma is trapped in the red cell column of the hematocrit and thus the uncorrected reading over-estimates the proportion of red cells in the sample; when this correction has been applied one may speak of the "true" venous hematocrit. Secondly, this corrected venous hematocrit value still over-estimates the proportion of red cells in the circulating blood as a whole and must be multiplied by a factor of approximately 0.9 to give an estimate of "body hematocrit." Although these concepts are accepted by the majority of investigators, the precise value of the ratio $\frac{\text { body hematocrit }}{\text { venous hematocrit }}$ is in doubt; moreover it has been suggested that the ratio may be inconstant so that it cannot safely be used to deduce blood volume from an estimate of either red cell volume or plasma volume. Accordingly, it is generally held that the only reliable estimates of total blood volume are those based on separate measurements of both red cell volume and plasma volume.

If, in fact, the body/venous hematocrit ratio appeared to be inconstant, the inconstancy could

1 U. S. Public Health Service Research Fellow and, more recently, Senior Assistant Surgeon (R.), U. S. Public Health Service.

2 British Council Research Fellow on leave from 2nd Medical University Clinic, Vienna. arise either from a true physiological variation between different subjects, or from the effect of abnormal states of the circulation, or it might depend solely on some systematic error in the measurement of either red cell volume or plasma volume. If the observed difference between the body hematocrit and the venous hematocrit is due to the fact that blood in the small capillary vessels has a very much lower hematocrit than blood in large vessels, it is possible to conceive of only a very few conditions (see Discussion) in which a variation in the body/venous hematocrit ratio could be expected to occur. If on the other hand the observed discrepancy between body hematocrit and venous hematocrit depends upon a systematic error in measuring, for example, plasma volume, it can be calculated that the discrepancy should vary with the level of venous hematocrit. In fact very few observers have estimated the body/venous hematocrit ratio over a sufficiently wide range to test this. Mollison, Veall, and Cutbush (1) reported measurements in newborn infants covering the observed venous hematocrit range 19 to 70 per cent; they found the ratio to be constant over this range although the absolute value was a little lower than that previously described for normal adults. Similar studies in adults, over the hematocrit range 25 to 72 per cent have been reported (2-4); however, very few anemic subjects were included and no conclusions can be drawn as to the effect of anemia or polycythemia upon the constancy of the ratio.

The present paper reports twenty-eight simultaneous plasma volume and red cell volume measurements on adult subjects with hematocrits ranging from 9 to 82 per cent. The ratio of the body hematocrit to the venous hematocrit was found to be constant throughout this range. The paper includes a discussion of various factors which determine the value assigned to the ratio. 


\section{METHODS}

\section{Subjects}

Twenty-eight measurements were made on a group of nineteen subjects; two were normal volunteers, seventeen were patients (Table I). Not more than two measurements were made on the same subject; generally the second measurement was made after some major change in hematocrit had occurred-for example, in a patient with polycythemia vera, before and after radiation therapy.

\section{Plasma volume}

Plasma volume was measured using the dye T-1824 (Evans Blue). All subjects had fasted for 12 hours and had been recumbent for at least 30 minutes before the procedure. Twenty $\mathrm{ml}$. of a 0.075 per cent solution of dye (Imperial Chemical Industries Batch PD/RS. 337/ 44) was injected intravenously from a calibrated syringe and this was followed by an injection of $\mathrm{P}^{22}$ labelled red cells (see below). Immediately before injection, $15 \mathrm{ml}$. of blood was withdrawn and three further $15 \mathrm{ml}$. samples were withdrawn at 15-minute intervals after injection (i.e., at 15, 30, and 45 minutes). The blood was in each case taken into a syringe containing a few drops of liquid heparin and mixed in the syringe; $5 \mathrm{ml}$. was put into a tube for measurement of radio-activity (see below) and the remaining $10 \mathrm{ml}$. was delivered gently, without bubbling, into a dry test tube. A sample was removed immediately for determination of packed cell volume (observed venous hematocrit). Any blood remaining on the walls of the test tube was removed on a cotton swab, slightly moistened with saline solution. The tube was then tightly capped and centrifuged at 3000 r.p.m. for approximately $\mathbf{4 0}$ minutes. After centrifugation the plasma was transferred to another dry test tube and kept at room temperature for not more than 3 to 4 hours before being used for colorimetric analysis.

Approximately $0.02 \mathrm{ml}$. of the injection solution was diluted in $3 \mathrm{ml}$. of pre-injection plasma, delivered from a calibrated $3 \mathrm{ml}$. pipette. The volume of injection solution was chosen to give a concentration of the dye in plasma essentially the same as that found in the initial postinjection blood sample. The small volume of injection solution was delivered from an "Agla" micrometer-syringe, with which very satisfactory precision can be attained (5).

All samples were read in a photo-electric colorimeter using a deep red filter (combination of Ilford 803 and 205 ; [1]).

When the dye concentrations were plotted against time it was evident that there was some variability in the dye disappearance curves in different cases; furthermore, it was often difficult to decide the best possible straight line to be drawn through the three points. It was considered that these variations and difficulties were largely the results of technical error and did not necessarily represent true variations in the individual subjects. Accordingly, the dye disappearance rates in all twenty-eight determinations were combined and a mean loss rate of 10 per cent per hour was found. In determining the dye concentration at zero time in each subject, the values for the 15, 30 and 45-minute blood samples (mean-30 minutes) were averaged and corrected for a 5 per cent loss of dye. Plasma volume was then calculated in the usual way by comparing the dye concentration at zero time with the dye concentration of the standard.

\section{Red cell volume}

Red cell volume was measured using a modification (6) of the radio-active phosphorus method described by Reeve and Veall (7). With the modified method, in a series of duplicate determinations on ten normal males, the standard error of the difference between duplicate measurements was found to be $58 \mathrm{ml}$. (a coefficient of variation of 2.7 per cent) (6). In preparing the radio-actively tagged cells for injection, the cells were washed in a mixture of 3 per cent of plasma in ice-cold saline (6) ; the "extracellular" radio-activity of the injection suspension was measured and was in all cases less than 1 per cent of the total activity of the suspension.

The washed $\mathrm{P}^{39}$-tagged red cells were injected about 30 seconds after completion of the injection of Evans Blue dye. Five $\mathrm{ml}$. aliquots from the 15, 30, and 45-minute blood samples were used for the analyses of radio-activity.

\section{The body hematocrit}

The body hematocrit was calculated from:

$$
\frac{\text { Red Cell Volume }}{\text { Red Cell Volume plus Plasma Volume }}
$$

\section{The venous hematocrit}

The packed cell volume was determined using Wintrobe hematocrit tubes and a centrifuge having a radius of $15 \mathrm{~cm}$. from the spindle centre to the bottom of the hematocrit tube. The tubes were spun for 30 or $55 \mathrm{~min}$ utes at 3000 r.p.m.; the longer time was used in the later cases after it had been shown that more consistent results could thus be obtained ( 8 ). The observed packed cell volume (excluding the buffy coat) was corrected for plasma trapped in the red cell column, using the calibration curve appropriate to 30 minutes or 55 minutes centrifugation (8). The corrected values are described as the "true" venous hematocrit.

Packed cell volumes were determined on the pre-injection sample and on the three post-injection samples. In calculating the body/venous hematocrit ratio, the true venous hematocrit was taken as the mean of the true packed cell volumes on all four blood samples.

\section{RESULTS}

The results of a comparison of the body hematocrit with the true venous hematocrit (i.e., observed venous hematocrit corrected for trapped plasma) are shown in Table $I$, with various other data. The mean value for the body/venous he- 


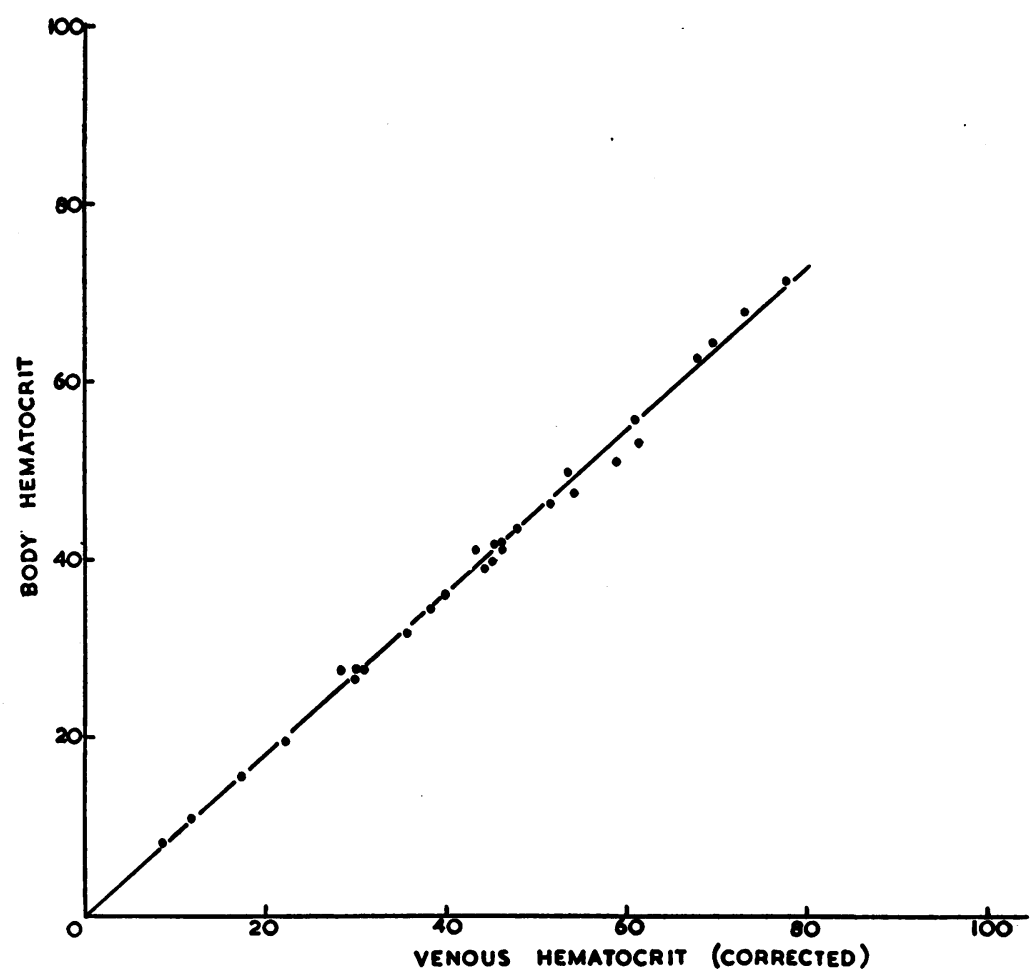

Fig. 1. Estimates of Body Hematocrit, Based on Twenty-eight Simultaneous Measurements of Red Cell Volume and Plasma Volume, Plotted against Observed Venous Hematocrit, Corrected for Trapped Plasma

The line is drawn from the regression equation: $\mathrm{BH}=0.9073 \mathrm{VH}+0.04$, calculated by the method of least squares from the points relating body hematocrit $(\mathrm{BH})$ to venous hematocrit (VH).

matocrit ratio obtained from these data is 0.910 (0.9098), with a standard deviation of 0.026 .

Measurements covered the observed hematocrit range 9 to 82 per cent and in Figure 1 the body hematocrit is plotted against the true venous hematocrit. The relationship of the body hematocrit to the venous hematocrit over this range appears to be constant, the calculated regression line passing almost exactly through the origin.

\section{DISCUSSION}

There are still some workers (9) who believe that the discrepancy between the body hematocrit and venous hematocrit may depend upon a systematic error in the measurement of plasma volume. However it is unnecessary to postulate such an error for it seems likely, on theoretical grounds alone, that a discrepancy exists. For example it has been shown that blood streaming through fine tubes has a lower hematocrit than blood in large tubes (10). In the body this phenomenon seems very likely to lead to a discrepancy between the venous hematocrit and the whole body hematocrit. The observation in the present paper that the body/venous hematocrit ratio is independent of the level of the venous hematocrit strongly suggests that there is no systematic over-estimate of plasma volume; for if there were, relatively high ratios would be obtained in polycythemic subjects and lower ratios in anemic subjects.

One piece of evidence which is valuable because it does not depend on plasma volume estimation is that from replacement transfusions. Veall and Mollison (11) found that the removal of red cells was more efficient than would have been expected if the venous hematocrit were representative of the distribution of red cells and plasma in the blood as a whole; the discrepancy could best be explained by supposing that the blood in the body as a whole 
had a hematocrit value about 0.9 times that of venous blood.

Although most authors accept the concept of a body/venous hematocrit ratio, there remains some disagreement as to the value which should be assigned to the ratio (see Table II). The differences shown in Table II are not in fact significant (at the level $\mathrm{p}=0.05$ ). Nevertheless, different workers are bound to assign slightly different values to the ratio due to lack of uniformity in the interpretation of data; this may be illustrated by the following two examples.

Estimation of the true venous hematocrit. Several factors will affect the value chosen for the true venous hematocrit. Firstly, it is the practice of some authors to include the white cell layer in their reading of the observed packed cell volume; this of course results in the reporting of lower values for the body/venous hematocrit ratio than when the buffy coat is excluded. Secondly, although most authors agree that the observed packed cell volume must be corrected for trapped plasma, there is considerable variation in the correction factor which is applied $(13,14)$. The higher the correction factor used for the plasma trapped in the packed cell column, the higher will be the value obtained for the body/venous hematocrit ratio. A third factor of importance will be the choice of blood samples used for determining the venous hematocrit. In the present investigation, it was decided to use the mean packed cell volume of all four blood samples. However, as Reeve (15) has pointed out, when multiple small blood samples are withdrawn from a subject, there is sometimes a slight progressive fall in the packed cell volume of successive samples. A slight pro-

TABLE II

The body/venous hematocrit ratio in adults, according to various authors*

\begin{tabular}{|c|c|c|c|c|}
\hline \multirow[b]{2}{*}{ Reference } & \multirow{2}{*}{$\begin{array}{c}\text { Number } \\
\text { of } \\
\text { cases }\end{array}$} & \multirow{2}{*}{$\begin{array}{c}\text { Hema- } \\
\text { tocrit } \\
\text { range }\end{array}$} & \multicolumn{2}{|c|}{$\frac{\text { Body }}{\text { Venous }}$ Hematocrit rati } \\
\hline & & & Mean & (S.D.) \\
\hline $\begin{array}{l}\text { Gibson et al. (12) } \\
\text { Reeve and Veall (7) } \\
\text { Nachman et al. (2) } \\
\text { Berson and Yalow (4) } \\
\text { Present authors }\end{array}$ & $\begin{array}{l}40 \\
13 \\
40 \\
25 \\
28\end{array}$ & $\begin{array}{r}38-49 \\
38-47 \\
26-59 \\
16-72 \\
9-82\end{array}$ & $\begin{array}{l}0.906 \\
0.915 \\
0.895 \\
0.924 \\
0.910\end{array}$ & $\begin{array}{l}(0.082) \\
(0.012) \\
(0.067) \\
(0.040) \\
(0.026)\end{array}$ \\
\hline
\end{tabular}

* The mean and S.D. of some of the results $(2,7)$ have been taken from the paper by Reeve (15). The other S.D.'s were calculated from published data.
TABLE III

Effect of deducing body/venous hematocrit ratio from different venous samples

\begin{tabular}{cc}
\hline \hline & Body \\
Samples used for venous hematocrit & $\frac{\text { Venous }^{*}}{}$ \\
\hline Pre-injection plus three post-injection & 0.910 \\
Pre-injection alone & 0.903 \\
\hline
\end{tabular}

* Mean of twenty-eight measurements.

gressive fall in the venous hematocrit was observed in eleven of the twenty-eight determinations included in this study; however this fall was less than one hematocrit division in all but two cases. The "fall" was greatest between the pre-injection and first post-injection blood sample. Since the venous stasis preceding the withdrawal of the preinjection sample was generally more pronounced than that preceding the post-injection samples, the "fall" in hematocrit may have been in part related to stasis. In any event, since the four blood samples generally showed very close agreement it was decided that a mean of the four values would be most representative of the venous hematocrit at the time of the blood volume measurement. Table III shows the effect upon the ratio of recalculating the data for the twenty-eight measurements, using the packed cell volume of the pre-injection blood sample alone.

The interpretation of dye disappearance curves. When the dye concentration of successive samples is plotted against time, the slope is found to be curvilinear, even when dye concentration is plotted on a logarithmic scale; the result of an actual experiment is shown in Figure 2. To illustrate the effects of extrapolating back to zero time from points obtained relatively soon or late after the injection of the dye, a solid line has been drawn through the points obtained within the first 40 minutes after injection of the dye and an interrupted line through the points obtained between 40 and 80 minutes after injection. The effect of these two extrapolations upon the value for the plasma volume and hence, upon the body/venous hematocrit ratio, is shown. It must be admitted that differences of the magnitude illustrated here are unlikely to occur in practice, for most workers take their blood samples within the first hour after injection.

-Another method of estimating dye concentration 


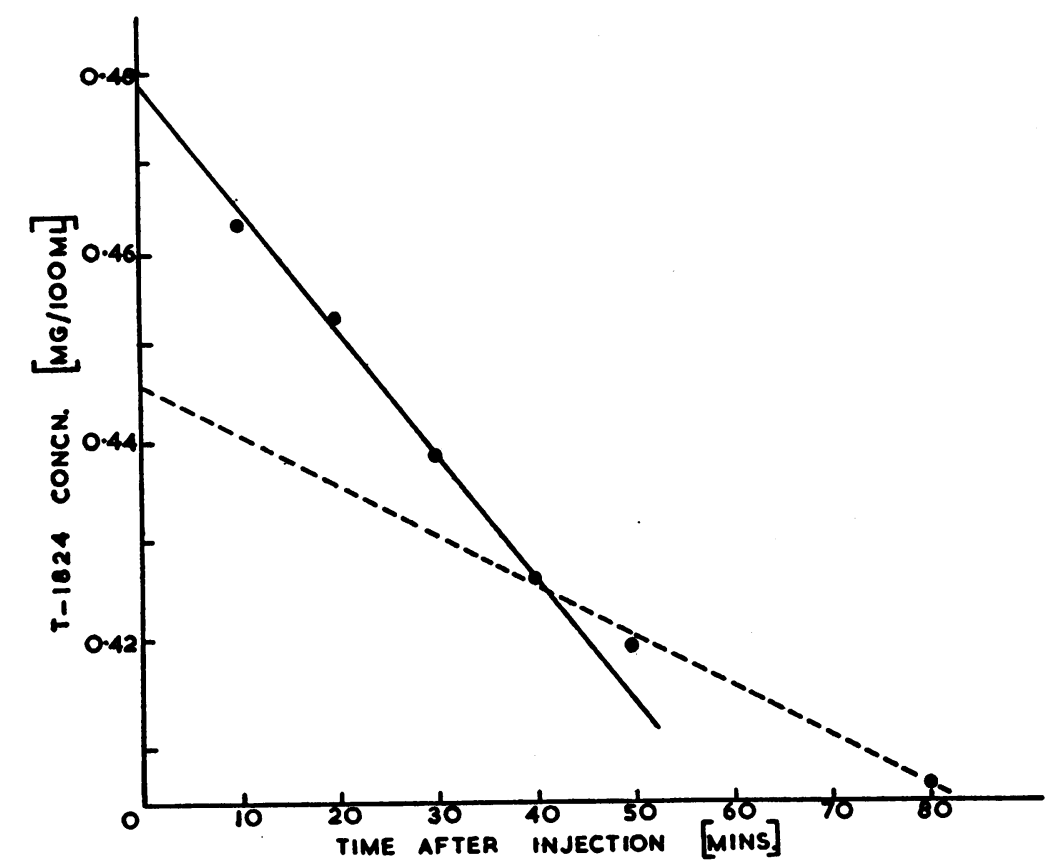

Fig. 2. Observations of Dye Concentration (Plotted on a Logarithmic Scale) on a Normal Subject during the 80 Minutes following an Injection of Evans Blue

The solid line drawn through the points obtained during the first 40 minutes led to a plasma volume estimate of $3190 \mathrm{ml}$. with a body/venous hematocrit ratio of 0.917 ; the dotted line drawn through the points obtained during the second 40 minutes led to a plasma volume estimate of $3420 \mathrm{ml}$. with a body/venous hematocrit ratio of 0.880 .

at zero time, used for example in the present paper, is to assume a constant rate of dye loss during the first $\mathbf{4 5}$ minutes after injection and to apply a correction to the observed concentration rather than trying to estimate the rate of loss in each case.

It is obvious that the use of these different conventions will lead to different estimates of plasma volume and thus to different estimates of the body/ venous hematocrit ratio in a given patient.

In practice most workers have found values within the range 0.90 to 0.92 in normal adults. If a worker elects not to determine a value for the body/venous hematocrit ratio under his own conditions of measurement, it seems justifiable for him to select a value within this range.

It has been mentioned that there may be a few clinical conditions in which the body/venous hematocrit ratio may actually depart significantly from the constant value described above. The rarity of these conditions is not surprising if one considers the physiological interpretation of the discrepancy between body hematocrit and venous hematocrit. It can be shown that in order to produce a body hematocrit 10 per cent lower than the venous hematocrit, assuming that 20 per cent of the total blood volume is distributed in the capillary bed (16), one must postulate a hematocrit in capillary blood which is only half as great as the hematocrit in the venous blood. It is apparent that in order to raise the body/venous hematocrit ratio significantly (say, from 0.90 to 0.95 ) one would require either (a) complete shutdown of half of the capillary bed, or (b) very great calibre enlargement of half the capillary bed, or (c) a reservoir of blood somewhere in the body, wherein there was circulating at least 15 per cent of the total blood volume, having a hematocrit one third higher than the venous hematocrit. There are very few clinical conditions in which these requirements 
are likely to be fulfilled. For example it is likely that during prolonged oligemic shock, capillary blood flow is so radically altered as to disturb the normal body/venous hematocrit ratio. In some patients with severe anemia accompanied by massive splenomegaly, there may be a large enough volume of "concentrated" blood flowing through the spleen to produce a body/venous hematocrit ratio close to 1.0 (17). However, massive splenomegaly by itself will not raise the body/venous hematocrit ratio in the non-anemic individual, presumably because the spleen's ability to concentrate blood is limited. For example, in the present series, there were twelve patients with moderate or gross splenomegaly, only one of whom was anemic; the average body/venous hematocrit ratio in these twelve patients was 0.909 , that is to say, almost precisely the same as that of the whole series. Finally, it has been suggested (18) that in patients with congestive cardiac failure, the measurement of plasma volume by the dye method may be seriously in error. If this is true it seems best in this condition to deduce total blood volume from a measurement of red cell volume alone, using a standard correction factor for the body/ venous hematocrit ratio.

The fact, demonstrated clearly by the present data, that the body/venous hematocrit ratio does not vary with the venous hematocrit is of considerable importance. It implies that if a worker standardizes his conditions of measurement and determines the value for the body/venous hematocrit ratio under these conditions, he may then proceed with confidence to use this value to deduce total blood volume from a measurement either of red cell volume or plasma volume alone. Alternatively, using the conventions described in the present paper, the value of the ratio may be assumed to be 0.91 .

The method of estimating blood volume is then as follows: The observed venous hematocrit is corrected for trapped plasma (8) and then multiplied by 0.91 to obtain the "body hematocrit" $(\mathrm{BH})$. Blood volume is then given by:

$$
\text { Red cell volume } \times \frac{100}{\mathrm{BH}}
$$

or

$$
\text { Plasma volume } \times \frac{100}{100-\mathrm{BH}}
$$

\section{SUM MARY}

The ratio $\frac{\text { body hematocrit }}{\text { venous hematocrit }}$ has been estimated in adults over the observed venous hematocrit range 9 to 82 per cent and found to be constant (twenty-eight measurements). The value for the ratio was 0.910 with a standard deviation of 0.026 . It is pointed out that the exact value assigned to this ratio depends to a small extent on interpretation, but that this does not affect its usefulness in deducing blood volume from a measurement of red cell volume or plasma volume alone.

\section{ACKNOWLEDGMENTS}

We should like to thank Drs. J. D. Abbatt, J. F. Goodwin, and J. C. Hawksley and Professors J. M. McMichael and M. L. Rosenheim for allowing us to make observations upon patients under their care. Dr. C. M. Scott of Imperial Chemical Industries kindly supplied the Evans Blue dye.

\section{REFERENCES}

1. Mollison, P. L., Veall, N., and Cutbush, M., Red cell and plasma volume in newborn infants. Arch. Dis. Child., 1950, 25, 242.

2. Nachman, H. M., James, G. W., III, Moore, J. W., and Evans, E. I., A comparative study of red cell volumes in human subjects with radioactive phosphorous tagged red cells and T-1824. J. Clin. Invest., 1950, 29, 258.

3. Wasserman, L. R., Yoh, Tse-fei, and Rashkoff, I. A., Blood volume determination: comparison of T-1824 and $\mathrm{P}^{22}$ labeled red cell methods. J. Lab. \& Clin. Med., 1951, 37, 342.

4. Berson, S. A., and Yalow, R. S., The use of $\mathrm{K}^{*}$ or $\mathrm{P}^{*}$ labeled erythrocytes and Im tagged human serum albumin in simultaneous blood volume determinations. J. Clin. Invest., 1952, 31, 572.

5. Barnes, D. W. H., Loutit, J. F., and Reeve, E. B., A comparison of estimates of circulating red blood cell volume given by the Ashby marked red cell method and the T-1824-haematocrit method in man. Clin. Sc., 1948, 7, 135.

6. Chaplin, H., Jr., Precision of red cell volume measurement using $\mathrm{P}^{\mathrm{s}}$-labelled cells. J. Physiol., In press.

7. Reeve, E. B., and Veall, N., A simplified method for the determination of circulating red-cell volume with radio-active phosphorus. J. Physiol., 1949, 108, 12.

8. Chaplin, H., Jr., and Mollison, P. L., Correction for plasma trapped in the red cell column of the hematocrit. Blood, 1952, 7, 1227.

9. Prentice, T. C., Berlin, N. I., Hyde, G. M., Parsons, R. J., Lawrence, J. H., and Port, S., Total red 
cell volume, plasma volume, and sodium space in congestive heart failure. J. Clin. Invest., 1951, 30, 1471.

10. Fåhraeus, R., The suspension stability of the blood. Physiol. Rev., 1929, 9, 241.

11. Veall, N., and Mollison, P. L., The rate of red cell exchange in replacement transfusions. Lancet, 1950, ii, 792.

12. Gibson, J. G., 2nd, Peacock, W. C., Seligman, A. M., and Sack, T., Circulating red cell volume measured simultaneously by the radioactive iron and dye methods. J. Clin. Invest., 1946, 25, 838.

13. Maizels, M., Intercellular plasma in the centrifuged erythrocytes of normal human blood. Quart. J. Exper. Physiol., 1945, 33, 129.

14. Chapin, M. A., and Ross, J. F., The determination of true cell volume by dye dilution, by protein dilu- tion, and with radioactive iron. Error of the centrifuge hematocrit. Am. J. Physiol., 1942, 137, 447.

15. Reeve, E. B., Use of radioactive phosphorus for the measurement of red-cell and blood volume. Brit. M. Bull., 1952, 8, 181.

16. Gibson, J. G., 2nd, Seligman, A. M., Peacock, W. C., Aub, J. C., Fine, J., and Evans, R. D., The distribution of red cells and plasma in large and minute vessels of the normal dog, determined by radioactive isotopes of iron and iodine. J. Clin. Invest., 1946, 25, 848.

17. Verel, D., Personal communication.

18. Ross, J. F., Chodos, R. B., Baker, W. H., and Freis, E. D., The blood volume in congestive heart failure. Tr. A. Am. Physicians, 1952, 65, 75. 